\title{
Seasonal variability of periphyton nutrient status and biomass on artificial and natural substrates in a tropical mesotrophic reservoir
}

Variação sazonal do estado nutricional e da biomassa do perifíton em substrato artificial e natural em um reservatório tropical mesotrófico

Carla Ferragut, Alexandre Ferreira Rodello and Carlos Eduardo de Mattos Bicudo

Instituto de Botânica, Núcleo de Pesquisa em Ecologia, Rua Miguel Stefáno, 3687, Água Funda, CP 68041, CEP 04301-912, São Paulo, SP, Brazil e-mail: carlaferragut@yahoo.com.br; alexandre.rodello@hotmail.com; cbicudo@terra.com.br

Abstract: Aim: Study aimed at evaluating the periphytic community seasonal variation, nutrient status and biomass on artificial and natural (Nymphaea spp., Utricularia foliosa Linnaeus) substrates at a shallow mesotrophic reservoir (Ninféias Reservoir) located in the Parque Estadual das Fontes do Ipiranga, São Paulo, southeast Brazil; Methods: Samplings for physical, chemical and biological characteristics was performed in winter (August-2006), spring (October-2006), summer (January-2007) and autumn (April-2007). Periphyton was collected growing on artificial (microscope glass slides, 28 days colonization) and natural substrate (Nymphaea spp. and Utricularia foliosa). Periphyton attributes studied were: chlorophyll $a$, dry mass, ash free dry mass, and $\mathrm{N}$ and P content; Results: During the study period was recorded the highest values of water transparency and $\mathrm{DO}$ in the winter, $\mathrm{PO}_{4}-\mathrm{P}$ and free $\mathrm{CO}_{2}$ in the spring, temperature and phytoplankton biomass in summer and autumn of DIN. The highest biomass values were recorded in winter and autumn. Periphyton $\mathrm{P}$ and $\mathrm{N}$ content varied seasonally on the substrates. Nymphaea spp. had the highest periphyton P content in summer, while $U$. foliosa and artificial substrate presented in the spring. Higher periphyton $\mathrm{N}$ content in Nymphaea spp., $U$ foliosa and artificial substrate was recorded in the spring, winter and autumn, respectively. Periphyton and water ratio N: P molar indicated P-limitation, except the water in the spring (N-limitation). Conclusion: Periphyton N and P content and biomass variation was controlled by the seasonal scale. However, the microhabitat type seems to influence the periphyton nutrient status, especially in low nutrient availability in the environment.

Keywords: biomass, natural and artificial substrates, nutrient status, periphyton.

Resumo: Objetivo: Estudo avaliou a variação sazonal do estado nutricional e biomassa da comunidade perifítica em substrato artificial e natural (Nymphaea spp. e Utricularia foliosa Linnaeus) em reservatório mesotrófico raso (Reservatório das Ninféias, Parque Estadual das Fontes do Ipiranga, São Paulo, Brasil); Métodos: A amostragem das variáveis físicas, químicas e biológicas foi realizada no inverno (agosto-2006), primavera (outubro-2006), verão (janeiro-2007) e outono (abril-2007). O perifíton foi coletado de substrato artificial (lâminas de vidro, 28 dias de colonização) e do pecíolo de macrófitas aquáticas $U$. foliosa e $N y m p h a e a$ spp.). Os atributos estudados do perifíton foram: clorofila a, massa seca, massa seca livre de cinzas e conteúdo de N e P; Resultados: No período de estudo foram registrados os maiores valores de transparência da água e OD no inverno, de $\mathrm{P}_{-} \mathrm{PO}_{4}$ e $\mathrm{CO}_{2}$ livre na primavera, temperatura e biomassa fitoplanctônica no verão e de NID no outono. Os maiores valores de biomassa foram registrados no inverno e no outono. O conteúdo de $\mathrm{P}$ e $\mathrm{N}$ do perifíton variou sazonalmente em todos os substratos. $\mathrm{O}$ maior conteúdo de $\mathrm{P}$ foi observado em Nymphaea spp. no verão, em $U$. foliosa e substrato artificial na primavera. O maior conteúdo de $\mathrm{N}$ do perifíton em $N y m p h a e a$ spp., $U$. foliosa e substrato artificial foi registrado na primavera, inverno e outono, respectivamente. A razão N:P molar do perifíton e da água indicaram limitação por $\mathrm{P}$, exceto a da água na primavera. Conclusáo: A variação da biomassa e do conteúdo de $\mathrm{N}$ e $\mathrm{P}$ do perifíton foi controlada primariamente pela escala sazonal. Contudo, o tipo de microhábitat parece influenciar o estado nutricional do perifíton, principalmente, em condição de baixa disponibilidade de nutrientes no ambiente.

Palavras-chave: biomassa, substrato natural e artificial, estado nutricional, perifíton. 


\section{Introduction}

Periphyton communities have a milestone importance at the ecosystem level due to being primary producers and, thus, an energy source for invertebrates as well as habitat for many organisms (Stevenson, 1996). Mostly in shallow lakes and reservoirs, periphyton participates in the nutrients cycling, energy flux and the food web (Vadeboncoeur and Steinman, 2002). Regarding nutrient availability, periphyton may affect its renewal rate (Wetzel, 1993), promotes nutrient fluxes between pelagic and benthic zones (Zander and Vadeboncoeur, 2002), and also competes with macrophytes for light and carbon (Jones et al., 2002) and with phytoplankton for nutrients (Vadeboncoeur and Steinman, 2002).

Several studies demonstrated that physical and chemical substrate characteristics may affect species composition and abundance, as well as increase biomass and periphyton primary production (Burkholder, 1996; Vadeboncoeur and Steinman, 2002). Physical structure of a submersed surface constitutes a microhabitat that is chemically distinct and nutrient-enriched when compared to the overlying water (Burkholder, 1996). Studies reported that the periphyton structure growing on artificial and natural substrates may be significantly distinct one from the other (Townsend and Gell, 2005), whereas some other studies pointed for little (Rodrigues and Bicudo, 2001) or none structural difference between them (Lane et al., 2003). Comparison among different artificial substrates showed that chemical composition of different rocks had little influence on the biomass increment and species composition (Gross et al., 2003; Bergey, 2008). For Cattaneo and Amireault (1992), artificial substrates may simplify the periphyton community structure, considering that on the natural one response may be more representative of the environment impacts. On the contrary, Jones et al. (2002) demonstrated that relationship between periphyton and macrophyte may simply be a reflex of the changes at the microhabitat level caused by the host plant growth. In general, influence of substrate on the periphyton growth still is somewhat controversial as well as the possible existence of a substrate-periphyton interaction.

Biomass and nutrient status are commonly used to detect changes in the periphytic community (Stevenson, 1996), since they do respond to changes of aquatic ecosystems ecological quality (e.g. McCormick and O’Dell, 1996). Periphytic algal biomass temporarily varies due to its continuous accumulation, autogenic detachment processes and disturbances that retrigger community development (Stevenson, 1996). Furthermore, periphyton nutrient status can be modified by change in species composition, amount of non-algal nutrients and internal nutrient recycling (Kahlert, 1998; Stevenson, 1996), and the surrounding water nutrients availability (Burkholder, 1996).

Periphyton nutrient status may be estimated through nutrient limitation and evaluation of the optimal N or P supply and surplus (Stevenson, 1996; Kahlert et al., 2002; Kahlert and Pettersson, 2002). Regarding periphyton growing on macrophytes, experimental studies indicated the substrate influence on the periphyton biomass and nutrient status (Guariento et al., 2007, 2009). According to Wetzel (1993), periphyton nutrient status may be modified by the macrophyte nutrient release during senescence and decomposition processes. Rooted macrophytes may remobilize the sediments nutrient stock, particularly that of P, favoring the periphyton community (Carignan and Kalff, 1982). In Brazil, periphyton-substrate relationship was studied in flood plains, demonstrating that the type of substrate had little influence on the periphyton taxonomical structure (Rodrigues and Bicudo, 2001). Further studies showed that the substrate influence on the periphyton may vary according to the system's trophy, being greater in oligotrophic and mesotrophic systems than in eutrophic ones (Burkholder, 1996). According to Emisson and Moss (1980), macrophytes act as main nutrient sources for the periphyton in oligotrophic systems. Water column may, however, assume greater importance in the nutrient supply of eutrophic systems. Consequently, periphytonsubstrate relationship still is an enormous challenge to periphyton ecology, mainly in what refers to the nutrient status.

Considering periphyton-substrate relationship, present study aimed at evaluating the periphytic community nutrient status and biomass in artificial and natural substrate (Nymphaea spp.; Utricularia foliosa), contributing to a better understanding of the community structure in different microhabitats. Based on the study period, we aimed at answering the two following questions: 1) does seasonal scale equally affects the biomass variability and the periphyton nutrient status on distinct kinds of substrate? and 2) the natural substrate can influence the periphyton nutrient status, regardless of the seasonal scale? 


\section{Study Area}

Ninféias Reservoir (23 $\left.38^{\prime} \mathrm{S}, 4^{\circ} 37^{\prime} \mathrm{W}\right)$ is located in the Parque Estadual das Fontes do Ipiranga (PEFI), a preservation area for Atlantic Forest remnants within the urban area of the city of São Paulo (Figure 1). It is, in fact, a shallow reservoir $\left(Z_{\text {max }} 3.6 \mathrm{~m} ; Z_{\text {med }} 1.32 \mathrm{~m}\right.$; area $\left.5.433 \mathrm{~m}^{2}\right)$ classified mesotrophic (Bicudo et al., 2002). It was chosen for the present study due to being the only one in the Biological Reserve that has a great abundance of aquatic macrophytes in its littoral zone, such as Nymphaea elegans Hooker, Nymphoides indicum Kuntze and Utricularia foliosa Linnaeus, among others (Bicudo et al., 2002).
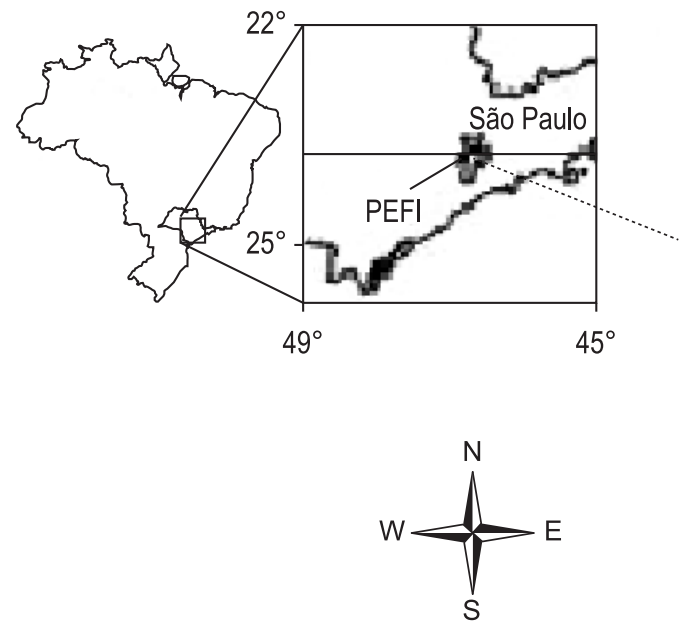

\section{Material and Methods}

To evaluate substrate influence on periphyton, sampling was performed on one artificial and two natural substrates. Periphyton samples were obtained from the petiole of Nymphaea spp. and Utricularia foliosa. Glass microscope slides were submersed at $25 \mathrm{~cm}$ depth for colonization. Exposure time was 28 days in all cases.

Periphyton samplings were randomized by previously sorting out the glass slide (artificial substrate). To sample the periphyton from natural substrates, first a natural stand was sorted out and then the plant from which periphyton was to be removed. Too young and senescent plants were excluded from all samplings.

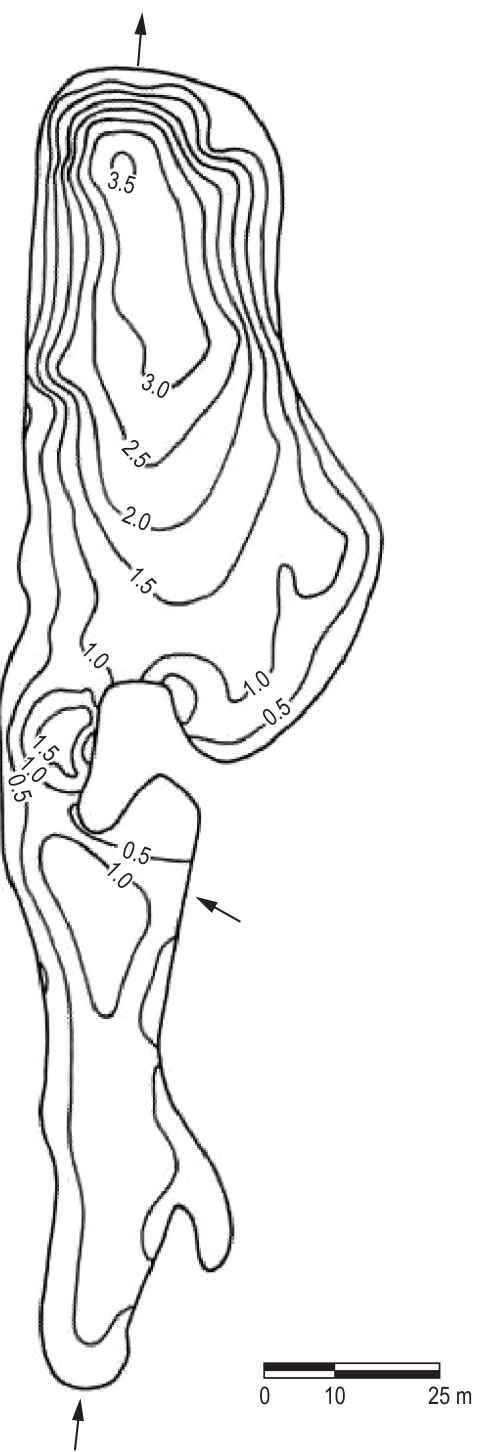

Figure 1. Map of Ninféias Reservoir with location of inflows (numbered arrows), outlet and sampling station (*) (Bicudo et al. 2002). 
Samplings for determination of physical, chemical and biological variables were performed in the winter (August 2006), spring (October 2006), summer (January 2007) and autumn (April 2007). Water sampling was carried out about $25 \mathrm{~cm}$ deep in the water column. Periphytic community samplings and those of the water surrounding each kind of substrate was performed in the Ninféias Reservoir littoral region. Artificial substrates were placed near the macrophyte stands (Nymphaea spp., U. foliosa).

Limnological variables studied were: underwater radiation (LiCor LI-250), temperature and electric conductivity (multiprobe YSI model 610-D), alkalinity (Golterman and Clymo, 1971), dissolved oxygen (Golterman et al., 1978), pH (pHmeter Jenway), inorganic dissolved carbon forms, nitrite and nitrate (Mackereth et al., 1978), ammonium (Solorzano, 1969), orthophosphate (Strickland and Parsons, 1960), total nitrogen and total phosphorus (Valderrama, 1981) and soluble reactive silica (Golterman et al., 1978). Samples for nutrients dissolved fractions were filtered using GF/F filters under low pressure $(<0.5 \mathrm{~atm})$. Most analyses were processed in the same sampling day, except for total nutrients that were frozen to be analyzed at most within 30 days from sampling date.

Samples for periphyton biomass determination were gathered by scraping and washing of artificial and natural substrates. Replicate periphyton samples (natural and artificial substrates) were filtered using glass fiber filters Whatman GF/F for determination of dry weight and ash free dry weight values (APHA, 1995). For chlorophyll $a$ determination (corrected for phaeophytin), ethanol 90\% was used for extraction according to Sartory and Grobbelaar (1984).

Autotrophic index (AI) is defined as the ratio between ash free dry weight and chlorophyll $a$ (APHA, 1995) values. Value of 200 represents the boundary condition theoretical limit between the autotrophic and heterotrophic conditions.

Periphyton P content was determined in triplicate samples using method described in Pompêo and Moschini-Carlos (2003). TN content was determined from triplicate samples using the micro-Kjeldhal method according to Umbreit et al. (1964). N and P content and N:P molar ratio was used to assess the periphyton nutrient status.

Statistical treatment of data was performed using descriptive analysis and arithmetic average as measurements of central tendency. Absolute dispersal degree of data was calculated using standard deviation, and relative dispersal through variation coefficient (VC). Pearson correlation coefficient $(r)$ was used to measure the linear relationship degree between abiotic variables and periphyton $\mathrm{P}$ and $\mathrm{N}$ contents. To establish the periphyton attribute's values significance degree obtained for each substrate, Variance Analysis (ANOVA, $\alpha=0.05$ ) was performed using Minitab for Windows, version 13.0. For a combined evaluation, multivariate Principal Components Analysis (PCA) was applied to the abiotic data. During analyses, covariance matrices were used with data transformed by $\log (\mathrm{x}+1)$. PCA was accomplished by using PC-ORD, version 4.10 (McCune and Mefford, 1999).

\section{Results}

\subsection{Limnological variables}

Limnological variables of substrate's surrounding water (artificial substrate, Nymphaea spp. and $U$. foliosa) at the reservoir littoral region varied according to spatial and seasonal scales (Figures 2a-l).

Water column depth at the artificial substrate and the Nymphaea spp. sampling station was $1.4 \mathrm{~m}$ during the entire study period, whereas at the $U$. foliosa one was $0.9 \mathrm{~m}$ during winter and spring and $0.5 \mathrm{~m}$ during summer and autumn due to seasonal distribution of the free-floating macrophyte stand. Based on the Secchi disc measurement, surrounding water transparency varied according to the season ( $\mathrm{VC}=26.1-56.3 \%$ ) (Figure $2 \mathrm{~h}$ ). The greatest transparency was measured on the artificial substrate and in the Nymphaea spp. stands during winter and autumn, whereas in the U. foliosa stand transparency reached almost the bottom of reservoir during all seasons.

Among the environment variables studied, temperature, $\mathrm{pH}$ and electric conductivity presented the least seasonal variation $(\mathrm{VC}=10.6-11.6 \%$, 4.4-9.2\% and 14.6-15.8\%, respectively; Figures $2 \mathrm{a}$, c, d). As expected, temperature values showed significant differences among seasons $(\mathrm{F}=315.98$; $p=0.000$ ), its greatest values observed during the summer, but no difference was detected among each type of substrate surrounding water. Electric conductivity presented significant difference only among seasons $(\mathrm{F}=238.36 ; p=0.000)$, its greatest values measured during the autumn (Figure 2c).

Free $\mathrm{CO}_{2}$ concentration in the all substrate's surrounding water varied seasonally $(\mathrm{VC}=18.8-22.5 \%)$, but significant difference was not observed at the spatial scales (Figure 2e). Dissolved oxygen varied seasonally for all substrates 

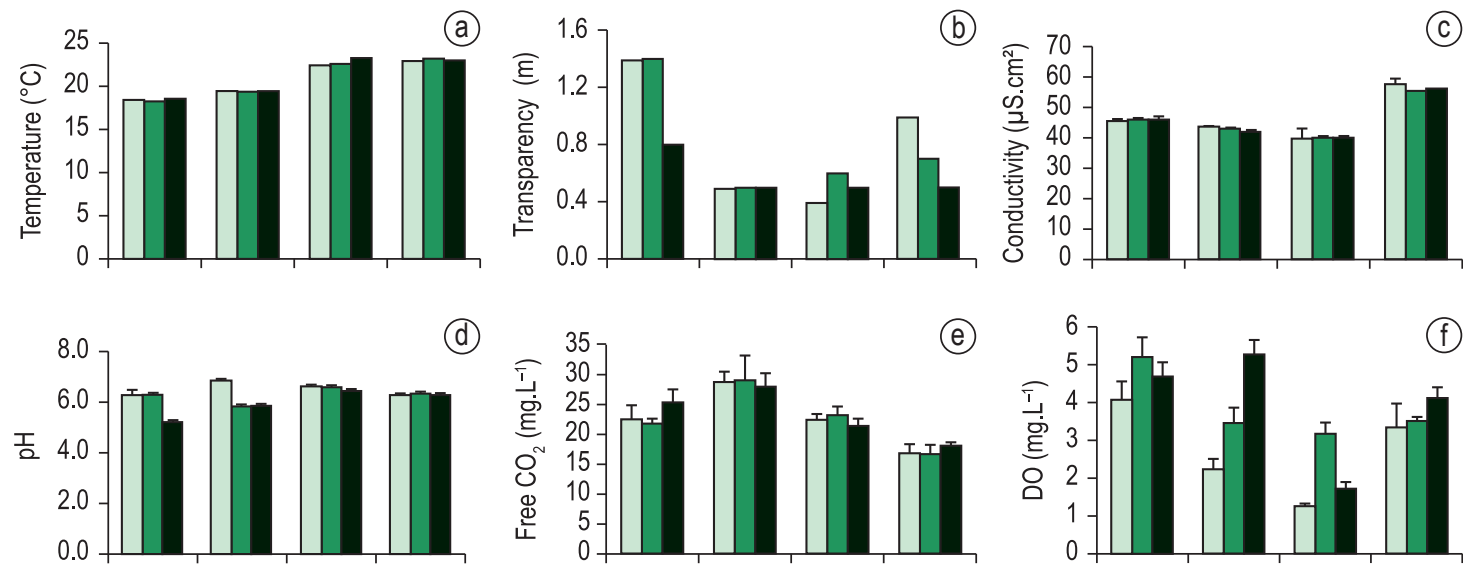

(d)
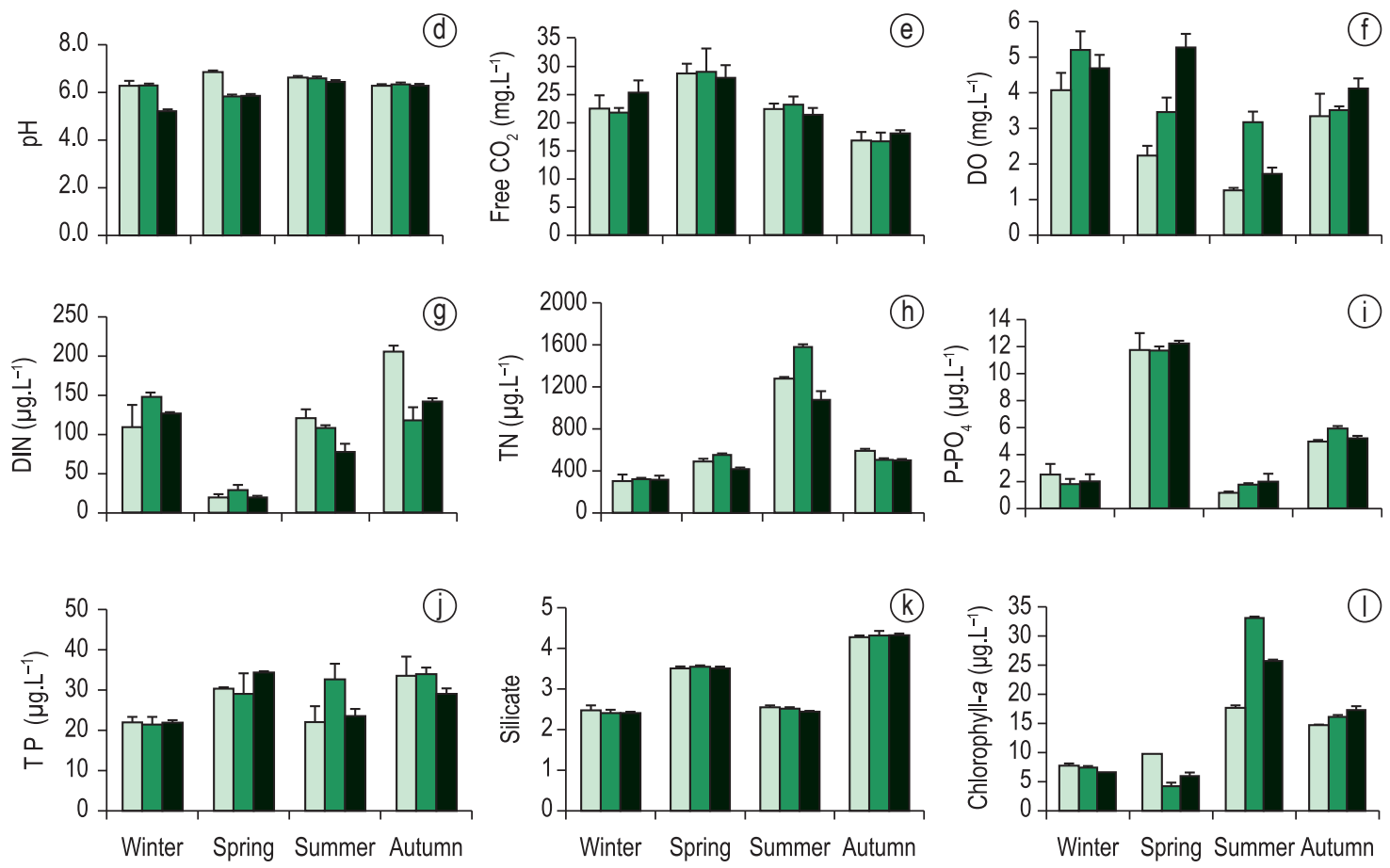

$\square$ Artificial $\square$ Nymphaea $\square$ Utricularia

Figure 2. Seasonal variation of environmental variables $(n=2, \mathrm{SD})$ measured for the surrounding water of each substrate type at Ninféias Reservoir.

$(\mathrm{VC}=24.2-48.8 \%)$ and its values were spatial-wise always smaller in the artificial one surrounding water than in the two natural ones (Figure 2f). However, only during spring and summer these values showed a significant difference $(\mathrm{F}=38.27$; $p=0.007 ; \mathrm{F}=46.12 ; p=0.006$, respectively), its greatest values measured on the natural than on the artificial substrate (summer 1.3-2.4-fold; spring 1.5-2.3-fold).

Regarding total nutrients at each substrate surrounding water (Figures $2 \mathrm{~g}-\mathrm{k}$ ), TN concentration presented a significant difference among distinct substrates only during the spring and autumn $(\mathrm{F}=35.90 ; p=0.008 ; \mathrm{F}=110.94 ; p=0.002$, respectively). Contrasting, TP concentration varied little seasonally $(\mathrm{VC}=19.3-21.5 \%)$ and, yet, it did not show significant differences both at spatial and seasonal scales. Significant differences were, however, detected after studying the surrounding water of different substrates and during some year seasons, such as DIN concentration in the summer $(\mathrm{F}=15.13 ; p=0.027)$ and autumn $(\mathrm{F}=36.67 ; p=0.008)$, and $\mathrm{P}-\mathrm{PO}_{4}$ concentration during the autumn $(\mathrm{F}=15.50 ; p=0.026)$. The greatest $\mathrm{P}-\mathrm{PO}_{4}$ availability in the water was detected during the spring, but in all other seasons of the year its values were below the method detection limit. $\mathrm{N}$ forms presented high seasonal variation $(\mathrm{VC}=69-137.8 \%)$, the greatest DIN values measured during summer and autumn.

Phytoplankton biomass (chlorophyll a) was significantly different for each kind of substrate surrounding water during spring and summer $(\mathrm{F}=66.50 ; p=0.003 ; \mathrm{F}=817.00$; $p=0.000$, respectively; Figure 21). During spring, phytoplankton biomass in the artificial substrate surrounding water was 2.5 and 1.7 times greater than in the Nymphaea spp. and $U$. foliosa 
stands, respectively. During summer, the greatest phytoplankton biomass values were measured at the Nymphaea spp. stand, being 1.8 and 0.8 times greater than that on the artificial substrate and at the $U$. foliosa stand, respectively. Phytoplankton biomass varied seasonally $(\mathrm{CV}=35.6-85.0 \%)$, its greatest values being detected during the summer.

Principal Component Analysis (PCA) was applied to the abiotic data to evaluate all limnological variables acting on the different substrates surrounding water (artificial, Nymphaea spp. and $U$. foliosa) during the entire study period (Figure 3, Table 1). Analysis resumed $87 \%$ of total data variability in the two first axes. At the negative side of axis 1 , spring sampling units were correlated with the $\mathrm{P}_{-} \mathrm{PO}_{4}$ and free $\mathrm{CO}_{2}$ greatest values $(r>0.7)$. On the contrary, all kinds of substrates summer sampling units were correlated with the greatest values of phytoplankton chlorophyll $a$ and water temperature $(r>0.8)$, whereas autumn sampling

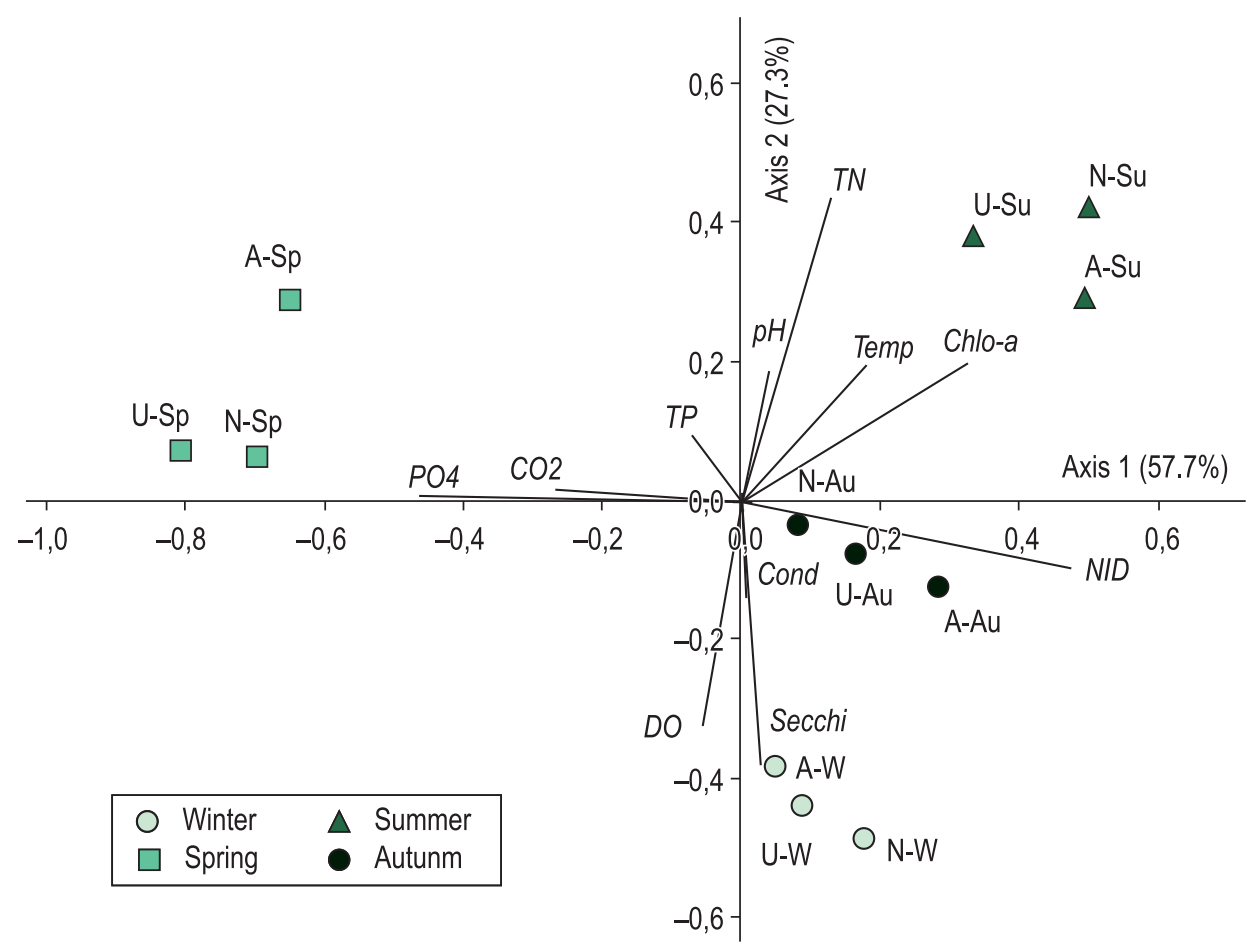

Figure 3. PCA of abiotic variables and scores biplot for the three substrates types during the study period. Scores abbreviation: first letter refers to the substrate type ( $\mathrm{A}=$ artificial; $\mathrm{N}=$ Nymphaea spp.; $\mathrm{U}=$ Utricularia folios $a)$ and second letter the season $(\mathrm{W}=$ winter; $\mathrm{A}=$ autumn; $\mathrm{Sp}=$ spring; $\mathrm{Su}=$ summer $)$. For correlation of variables with principal components and respective codes see Table 1.

Table 1. Limnological variables correlation with PCA principal components 1 and 2 and respective codes.

\begin{tabular}{lccc}
\hline & Code & Axis 1 & Axis 2 \\
\hline Chlorophyll a (phytoplankton) & Chlo-a & 0.736 & 0.579 \\
Electric conductivity & $\mathrm{Cond}$ & 0.113 & -0.482 \\
Dissolved oxygen & $\mathrm{DO}$ & -0.311 & -0.732 \\
Free $\mathrm{CO}_{2}$ & $\mathrm{CO}_{2}$ & -0.668 & 0.184 \\
Dissolved inorganic nitrogen & $\mathrm{NID}$ & 0.889 & -0.398 \\
Orthophosphate & $\mathrm{PO}_{4}$ & -0.882 & 0.130 \\
$\mathrm{pH}$ & $\mathrm{pH}$ & 0.262 & 0.559 \\
Temperature & $\mathrm{Temp}$ & 0.544 & 0.577 \\
Total nitrogen & $\mathrm{TN}$ & 0.464 & 0.854 \\
Total phosphorus & $\mathrm{TP}$ & -0.353 & 0.400 \\
Transparency (Secchi disc) & Secchi & 0.221 & -0.794 \\
Variance explained (\%) & & 57.7 & 27.3 \\
\hline
\end{tabular}


units were mainly correlated with the DIN greatest values $(r>0.7)$. At the negative side of axis 2 , winter sampling units were positioned, which were correlated with water transparency and DO values $(r>0.7)$. Axes 1 and 2 though represented the seasonal variation of environmental variables.

\subsection{Periphytic community}

Periphyton algal biomass (chlorophyll $a$ ) varied seasonally on all substrates. Algal biomass of the periphytic community developing on different types of substrates showed significant differences in all seasons (ANOVA winter: $\mathrm{F}=15.60 ; p=0.026$; spring: $\mathrm{F}=10.54 ; p=0,044$; autumn: $\mathrm{F}=32.71$; $p=0,009$; summer: $\mathrm{F}=8.57 ; p=0.050$ ) (Figure 4). The highest algal biomass was found in the $U$. foliosa microhabitat in the autumn, and values were 7.3 and 3.1 times greater than in the artificial and Nymphaea spp. substrates, respectively. Algal biomass was always greater on $U$. foliosa than on all other substrates, except for in the winter, when its increase was greater on Nymphaea spp. Different, periphyton on Nymphaea spp. and on the artificial substrate presented the greatest algal biomass in the winter. Periphyton algal biomass was positively correlated with Secchi disk depth $(r=>0.9)$.

Periphyton ash-free dry mass (AFDM) varied seasonally on all substrates, its greatest values observed during the autumn on all substrates (Figure 4). However, periphyton AFDM developing on $U$. foliosa was 1.7-fold greater than that on the artificial and Nymphaea spp. substrates. In general, periphyton biomass (chlorophyll $a$ and AFDM) tended to be greater during autumn and winter.

Periphyton growing on artificial substrate and on Nymphaea spp. presented the least autotrophic index (AFDM: chlorophyll $a$ ) in winter, indicating a more autotrophic community, whereas on $U$. foliosa it was dominantly heterotrophic during the same season (Figure 4).

Periphyton P content varied seasonally on all substrates (Figure 4). Periphyton growing on artificial substrate and on $U$. foliosa showed the highest P content in spring, while on Nymphaea spp. the greatest values were observed in the summer. During the last season, the periphyton
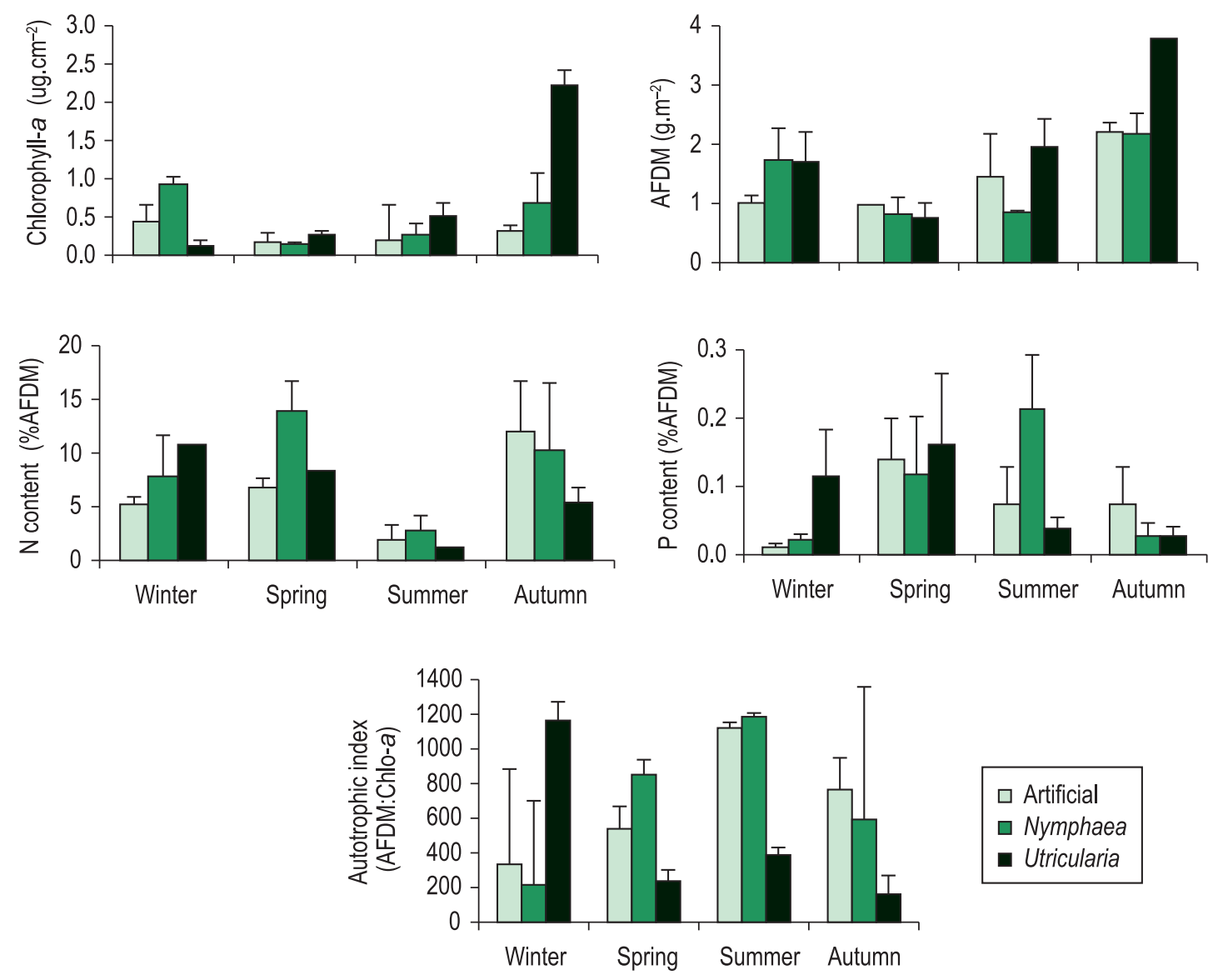

Figure 4. Seasonal variation of chlorophyll $a(n=2, \mathrm{SD})$, ash free dry mass (AFDM, $n=2, \mathrm{SD})$, N and P content $(n=3, S E)$ and periphyton autotrophic index $(n=2 ; S D)$ on natural and artificial substrates at the Ninféias Reservoir. 
P content on Nymphaea spp. was three and five times higher than on the artificial and $U$. foliosa, respectively. Compared to that on the artificial substrate, U. foliosa and Nymphaea spp. periphyton $\mathrm{P}$ content was on the average 1.3 times greater than on artificial substrate. Periphyton $\mathrm{P}$ content and $\mathrm{P}-\mathrm{PO}_{4}$ availability in water showed a positive Pearson correlation only for the artificial $(r=0.8$; $p=0.028)$ and $U$. foliosa $(r=0.744 ; p=0.034)$ substrates.

Periphyton N content developing on each substrate also varied seasonally (Figure 4 ). The least $\mathrm{N}$ value was registered during the summer for all substrates. In the autumn, the greatest $\mathrm{N}$ content was measured for the artificial substrate, whereas those for Nymphaea spp. and U. foliosa peaked during the spring. Periphyton $\mathrm{N}$ content and water DIN availability presented a positive, significant Pearson correlation only for the artificial substrate $(r=0.826, p=0.011)$, but no correlation for the natural ones.

According to the Redfield (1958) N:P molar ratio $(16 \mathrm{~N}: 1 \mathrm{P})$, periphyton was considered P-limited for all substrates $(\mathrm{N}: \mathrm{P}<16)$, but its limitation degree varied seasonally (Figure 5).
Periphyton P limitation least degrees were detected during the spring and summer for all substrates. Periphyton growing on Nymphaea spp. presented the best nutrient status in the summer.

Chlorophyll $a$ was positively correlated to N:P periphyton ratio (artificial: $r=0.872, p=0.005$; Nymphaea spp.: $r=0.800, p=0.017 ; U$. foliosa: $r=0.773, p=0.025)$, indicating increasing $\mathrm{P}$ limitation with increasing algal biomass.

Regarding the water and periphyton molar $\mathrm{N}: \mathrm{P}$ ratio, it was observed that both pointed for $\mathrm{P}$ limitation during the winter, summer and autumn (Figure 5). However, in the spring, water N:P ratio indicated limitation by $\mathrm{N}$, whereas periphyton $\mathrm{N}: \mathrm{P}$ ratio continued to indicate $\mathrm{P}$ limitation. Water and periphyton molar N:P ratios were decoupled from each other during the spring and other seasons, the periphyton P limitation being greater than the water's.

\section{Discussion}

This study showed that biomass amount and nutrient status of periphyton developing on artificial and natural substrates were controlled by the seasonal scale, but community response
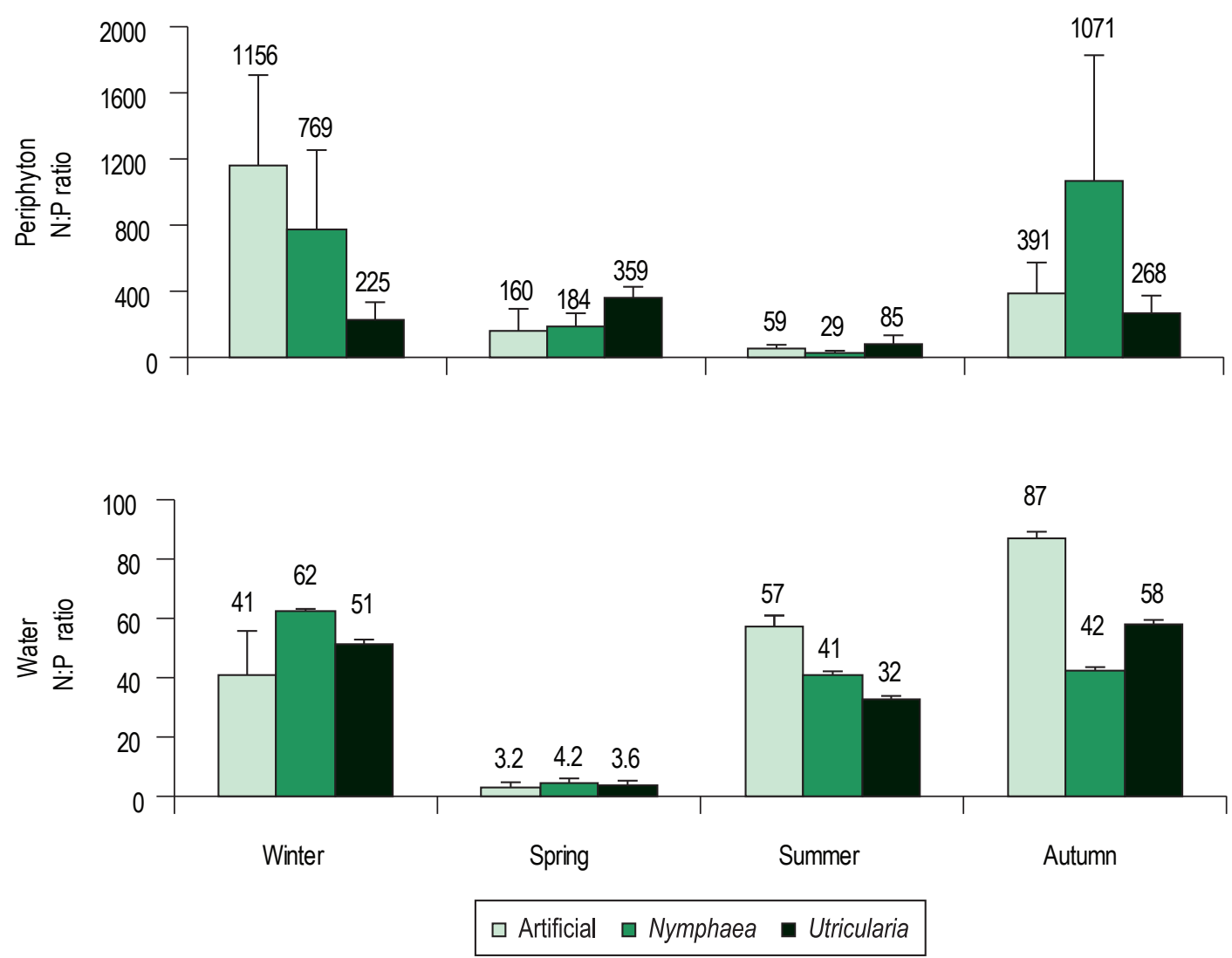

Figure 5. Periphyton N:P molar ratio and dissolved nutrients seasonal variation measured in the surrounding water of each substrate at the Ninféias Reservoir. 
was different in each microhabitat. Considering the overall limnological conditions, winter was characterized by greater water transparency; spring by greater $\mathrm{P}_{-} \mathrm{PO}_{4}$ and free $\mathrm{CO}_{2}$ concentration; summer by the greatest temperature values and high phytoplankton biomass; and autumn by the greater DIN availability. At the micro-environment scale, most of the substrate's water surrounding variables were not significantly different from each other, probably because the sampling points were too close to one another. Among variables analyzed, only DIN (summer and autumn), $\mathrm{P}_{-} \mathrm{PO}_{4}$ (autumn) and phytoplankton biomass (spring and summer) showed different concentrations in the substrate surrounding water. Periphyton biomass and nutrient status on different substrates were evaluated within the seasonal variation of limnological conditions.

Comparatively, periphyton growing on artificial and Nymphaea spp. substrates was dominantly autotrophic and presented great photosynthetic biomass (chlorophyll a) during the winter. Regarding all seasons, winter was the one to show high water transparency, little phytoplankton biomass and good nutrient availability (mainly DIN). These limnological characteristics favored periphyton biomass increase. Other environmental factors such as substrate stability, temperature, nutrients and grazers may influence the distribution and benthic algae abundance, but adequate light is clearly a requisite for phototrophic existence (Hill, 1996). Phytoplankton biomass decrease may have also favored periphyton growth, since the latter shadowing by the phytoplankton is a requisite for light availability attenuation for periphyton (Vadeboncoeur and Steinman, 2002). Other studies performed in tropical shallow reservoirs also reported great seasonal biomass variability (Fermino, 2006; Moschini-Carlos et al., 2000), as well as great periphytic biomass increase in winter (July, dry period) (Vercellino and Bicudo, 2006; Borduqui et al., 2008; Moschini-Carlos et al., 2000).

On the contrary, periphyton on the $U$. foliosa showed the least photosynthetic biomass during the winter, when the community was dominantly heterotrophic. In the winter, despite of the limnological conditions be favorable to the periphytic community development, U. foliosa stands were clearly reduced and presented a high senescence degree. This fact certainly affected algal periphyton growth. Despite $U$. foliosa have wide distribution and high density in tropical reservoirs (Walker, 2004), the primary production may be reduced in winter as reported in streams (Camargo et al., 2006). In the autumn, U. foliosa periphyton presented higher photosynthetic biomass, being predominantly autotrophic. Periphyton biomass growth on $U$. foliosa reflected the drastic influence of the macrophyte stands reduction in the winter, and the more favorable limnological conditions for algal growth in the autumn.

The greater periphyton P content on the artificial substrate and $U$. foliosa was detected during the spring, when $\mathrm{P}$ availability in water was highest. Moreover, periphyton $\mathrm{P}$ content correlated positive and significantly with environment $\mathrm{P}$ availability only on the artificial substrate and $U$. foliosa. In these substrates, the periphyton $\mathrm{P}$ content was coupled with the greater water $\mathrm{P}-\mathrm{PO}_{4}$ availability. Relationship between water and periphyton $\mathrm{P}$ availability was demonstrated in various studies (e.g. Gaiser et al., 2004). Díaz-Olarte et al. (2007) showed that periphyton abundance associated with $U$. foliosa depended mostly on the changes in the water $\mathrm{P}_{-} \mathrm{PO}_{4}$ concentration.

Conversely, periphyton growing on Nymphaea spp. P content was not correlated with water nutrient availability. Orthophosphate availability in water in the summer was very low (> $\left.4 \mu \mathrm{g} . \mathrm{L}^{-1}\right)$, but periphyton developing on Nymphaea spp. presented the highest P content. These results point for a Nymphaea spp. influence on the community $\mathrm{P}$ availability, which may have acted as a source of P to periphyton. Nymphaea spp. is a rooted macrophyte and, thus, able of re-mobilize nutrients, mainly the P stocked in the sediments, making it available to the periphyton community (Carignan and Kalff, 1982; Burkholder, 1996). Recently, Guariento et al. (2009) showed that the periphyton growing on Typha domingensis was influenced by the labile compounds release from substrates, the substrate surface texture and the surrounding water resources availability. According to Burkholder and Wetzel (1990), loosely attached periphytic algae derive $25-60 \%$ of their P supply from the macrophyte.

Periphyton N content also presented great seasonal variability on all substrates, but only on the artificial one it was correlated with the environment $\mathrm{N}$ availability. Periphyton on the artificial substrate presented the highest $\mathrm{N}$ content during the autumn, a season that also was associated with the highest DIN availability in the water. Differently, during the spring the water N:P ratio indicated a strong $\mathrm{N}$ limitation $(\mathrm{N}: \mathrm{P}<5)$ and the DIN concentration was lower, but periphyton $\mathrm{N}$ content was higher 
(8.3-13.9\%). Furthermore, a drastic reduction of periphyton $\mathrm{N}$ content (1.3-2,8\%) occurred during the summer on all substrates, but water DIN concentration and water N:P ratio did not indicate $\mathrm{N}$ limitation. Presently, periphyton $\mathrm{N}$ content on the artificial substrate was correlated with $\mathrm{N}$ availability in the system, but this fact was not observed on the natural substrates.

Considering the nutrient limitation potential of the periphytic community based on the Redfield (1958: N:P < 16) and Kahlert (1998: N:P < 18) ratios, periphyton was highly $\mathrm{P}$ limited during all seasons on all substrates. These results agree with Huszar's et al. (2005) that indicated P as the most limiting nutrient to algal growth in Brazilian lentic ecosystems. Experimentally, Fermino (2006) concluded that phosphorus was the primary limiting nutrient in the Ninféias Reservoir. In tropical lentic ecosystems, different studies indicated $\mathrm{P}$ as the primary limiting factor for periphyton growth (França et al., 2009; Borduqui et al., 2008; Ferragut and Bicudo, 2009). Consequently, present study reinforces the fact that $\mathrm{P}$ is the primary limiting nutrient for the periphytic community in tropical shallow ecosystems.

Considering the periphyton N:P ratio predictive potential, presently periphyton and water N:P ratio indicated $\mathrm{P}$ limitation, except for during the spring. During the last season, water and periphyton $\mathrm{N}: \mathrm{P}$ ratio were completely uncoupled from each other, the water ratio indicating $\mathrm{N}$ limitation $(\mathrm{N}: \mathrm{P}<4.2)$ and the periphyton high $\mathrm{P}$ limitation $(\mathrm{N}: \mathrm{P}=57-109)$ for all substrates. Therefore, in the mesotrophic condition water $\mathrm{N}: \mathrm{P}$ ratio was somewhat predictive of the potential limitation of periphytic community. Experimentally, studies showed that periphyton $\mathrm{N}$ and $\mathrm{P}$ content increased with the water $\mathrm{N}$ and $\mathrm{P}$ concentration, and periphyton N:P tracked water N:P ratio (Hillebrand and Sommer, 1999; Stelzer and Lamberti, 2001; Ferragut and Bicudo, 2009). Environment ratio may, however, be useful to access limiting condition when the water concentration is close to the growth limiting level, for when nutrients are in excess their supplying ratio become irrelevant (Borchardt, 1996). In contrast, Francoeur et al. (1999) stated that periphyton nutrient content was weakly predictive in stream ecosystem. Thus, besides nutrient availability in the water, other factors should also be considered, such as internal recycling processes (Borchardt, 1996), nutrient delivery by living substrate (Burkholder, 1996; Kahlert and
Pettersson, 2002) and non-algal periphyton $\mathrm{N}$ and P (Francoeur et al., 1999).

Algal biomass and periphyton N:P ratio showed a significant and positive correlation, indicating that biomass increase was accompanied by $\mathrm{P}$ limitation increase. In shallow tropical reservoir, Borduqui et al. (2008) observed that periphyton $\mathrm{P}$ content was uncoupled to biomass increase. In temperate ecosystems, Kahlert et al. (2002) reported that patchiness in the algae nutrient status was not coupled to patchiness of biomass, indicating that internal nutrients and biomass were regulated by different factors. For Frost et al. (2005), periphytic algae play an important role towards determining the periphytic community $\mathrm{C}: \mathrm{N}: \mathrm{P}$ molar ratio as a whole.

Cattaneo et al. (1997) showed that seasonal modification of periphyton-macrophyte relationship may indicate absence of ecological interaction, since the modifications observed would be a mere reflex of the direct influence of changes occurring at the microhabitat level. Experimentally, Jones et al. (2002) called attention to the fact that correlation between periphyton and its substrate may simply reflect the microhabitat different conditions, not the periphyton-plant interaction. For Kahlert and Pettersson (2002), living substrates were important nutrient sources for periphytic algae and the importance of this nutrient supply did not decrease with the increasing system's trophy. Eminson and Moss (1980) reported that the specific relationship between periphyton and macrophyte is more evident under nutrient low availability condition. Present results suggest that seasonal variation of periphyton nutrient status on natural substrates was influenced by the microhabitat only in winter/ Utricularia and summer/Nymphaea. Differently, periphyton on the artificial substratum seemed more dependent on the nutrients availability from the surrounding water (high correlation between periphyton nutrients and water nutrients).

Finally, limnological conditions varied in the seasonal scale, and thus influenced the periphyton biomass increment and nutrient status, regardless of substrate type. Periphyton N and P content and biomass variation was controlled primarily by the seasonal scale. However, the microhabitat type seems to influence the periphyton nutrient status, especially in low nutrient availability in the environment. More studies are needed to improve the understanding of periphyton $\mathrm{N}$ and $\mathrm{P}$ stoichiometry in different substrates types, mainly in tropical ecosystem. 


\section{Acknowledgements}

To CNPq (Conselho Nacional de Desenvolvimento Científico e Tecnológico) for fellowship given to CEMB (Grant no 303876/2004-2).

\section{References}

American Public Health Association - APHA. 1995. Standard Methods for the Examination of Waters and Wastewaters. Washington: APHA/AWWA/WPCF.

BERGEY, EA. 2008. Does rock chemistry affect periphyton accrual in streams? Hydrobiologia, vol. 614, p. 141-150. http://dx.doi.org/10.1007/ s10750-008-9450-9

BICUDO, DC., FORTI, MC. and BICUDO, CEM., orgs. 2002. Parque Estadual das Fontes do Ipiranga (PEFI): unidade de conservação que resiste à urbanização de São Paulo. São Paulo: Ed. Secretaria do Meio Ambiente do Estado de São Paulo.

BORCHARDT, MA., 1996. Nutrients. In Stevenson, J., Bothwell, ML. and Lowe, RL., eds. Algal ecology: freshwater benthic ecosystems. San Diego: Academic Press. p. 183-227.

BORDUQUI, M., FERRAGUT, C. and BICUDO, CEM. 2008. Chemical composition and taxonomic structure vertical and seasonal variation of periphyton community in a shallow eutrophic reservoir (Garças Reservoir, São Paulo). Acta Limnologica Brasilensia, vol. 20, p. 381-392.

BURKHOLDER, JM. 1996. Interaction of benthic algae with their substrates. In Stevenson, RJ., Bothwell, ML. and Lowe, RL., eds. Algal ecology: freshwater benthic ecosystems. San Diego: Academic Press. p. 253-298.

BURKHOLDER, JM. and WETZEL, RG. 1990. Epiphytic alkaline phosphatase on natural and artificial plants in an oligotrophic lake: re-evaluation of the role of macrophytes as a phosphorus source for epiphytes. Limnology and Oceanography, vol. 35, p. 736-747. http://dx.doi.org/10.4319/ lo.1990.35.3.0736

CAMARGO, FM., PEZZATO, MM., HENRY-SILVA, GG. and ASSUMPÇÃO, AM. 2006. Primary production of Utricularia foliosa L., Egeria densa Planchon and Cabomba furcata Schult \& Schult. from rivers of the coastal plain of the State of São Paulo, Brazil. Hydrobiologia, vol. 570, p. 35-39.

CARIGNAN, R. and KALFF, J. 1982. Phosphorus release by submerged macrophytes: Significance to epiphyton and phytoplankton. Limnology and Oceanography, vol. 27, p. 419-427. http://dx.doi. org/10.4319/lo.1982.27.3.0419

CATTANEO, A. and AMIREAULT, MC. 1992. How artificial are artificial substrates for periphyton? Journal of the North American Benthological Society, vol. 11, p. 44-256. http://dx.doi.org/10.2307/1467389

CATTANEO, A., KERIMIAN, T., ROBERGE, M. and MARTY, J. 1997. Periphyton distribution and abundance on substrates of different size along a gradient of stream trophy. Hydrobiologia, vol. 354, p. 101-110. http://dx.doi. org/10.1023/A:1003027927600

DÍAZ-OLARTE, J., VALOYES-VALOIS, V., GUISANDE, C., TORRES, NN., GONZÁLEZBERMÚDEZ, A., SANABRIA-ARANDA, L., HERNÁNDEZ, AMM., DUQUE, SR., MARCIALES, LJ. and NUNEEZ-AVELLANEDA, M. 2007. Periphyton and phytoplankton associated with the tropical carnivorous plant Utricularia foliosa. Aquatic Botany, vol. 87, p. 285-291. http://dx.doi. org/10.1016/j.aquabot.2007.06.010

EMINSON, DF. and MOSS, B. 1980. The composition and ecology of periphyton communities in freshwater. British Phycological Journal, vol. 15, p. 429-446. http://dx.doi.org/10.1080/00071618000650431

FERMINO, FS. 2006. Avaliação sazonal dos efeitos do enriquecimento por $N$ e P sobre o perifiton em represa tropical rasa mesotrófica (Lago das Ninféias, São Paulo). Rio Claro: Universidade Estadual Paulista. [Tese de Doutorado em Ciências Biológicas].

FERRAGUT, C. and BICUDO, DC. 2009. Efeito de diferentes níveis de enriquecimento por fósforo sobre a estrutura da comunidade perifítica em represa oligotrófica tropical (São Paulo, Brasil). Revista Brasileira de Botânica, vol. 32, p. 569-583.

FRANÇA, RCS., LOPES, MRM. and FERRAGUT, C. 2009. Temporal variation of biomass and status nutrient of periphyton in shallow Amazonian Lake (Rio Branco, Brazil). Acta Limnologica Brasiliensia, vol. 21, p. 175-183.

FRANCOEUR, SN., BIGGS, BJF., SMITH, RA. and LOWE, RL. 1999. Nutrient limitation of algal biomass accrual in streams: seasonal patterns and a comparison of methods. Journal of the North American Benthological Society, vol. 18, p. 242-260. http://dx.doi.org/10.2307/1468463

FROST, PC, HILLEBRAND, $\mathrm{H}$ and KAHLERT, $\mathrm{M}$. 2005. Low algal carbon content and its effect on the C:P stoichiometry of periphyton. Freshwater Biology, vol. 50, p. 1800-1807. http://dx.doi.org/10.1111/ j.1365-2427.2005.01449.x

GAISER, EE., SCINTO, LJ., RICHARDS, JH., JAYACHANDRANA, K., CHILDERSA, DL., TREXLER, JC. and JONES, RD. 2004. Phosphorus in periphyton mats provides the best metric for detecting low-level P enrichment in an oligotrophic wetland. Water Research, vol. 38, p. 507-516. http:// dx.doi.org/10.1016/j.watres.2003.10.020

GOLTERMAN, HL. and CLYMO, RS. 1971. Methods for chemical analysis of freshwaters. Oxford: Blackwell 
Scientific Publications, International Biological Programme.

GOLTERMAN, HL., CLYMO, RS. and OHMSTAD, MAM. 1978. Methods for physical and chemical analysis of freshwaters. 2th ed. Oxford: Blackwell Scientific Publications, International Biological Program. (Handbook, no. 8).

GROSS, EM., FELDBAUM, C. and GRAF, A. 2003. Epiphyte biomass and elemental composition on submersed macrophytes in shallow eutrophic lakes. Hydrobiologia, vol. 506-509, p. 559-565. http://dx.doi. org/10.1023/B:HYDR.0000008538.68268.82

GUARIENTO, RD., CALIMAN, A., ESTEVES, FA., BOZELLI, RL., ENRICH-PRAST, A. and FARJALLA, VF. 2009. Substrate influence and temporal changes on periphytic biomass accrual and metabolism in a tropical humic lagoon. Limnologica, vol. 39, p. 209-218. http://dx.doi.org/10.1016/j. limno.2008.04.002

GUARIENTO, RD., CALIMAN, A., ESTEVES, FA., ENRICH-PRAST, A., BOZELLI, RL. and FARJALLA, VF. 2007. Substrate-mediated direct and indirect effects on periphytic biomass and nutrient content in a tropical coastal lagoon, Rio de Janeiro, Brazil. Acta Limnologica Brasiliensia, vol. 19, p. 331-340.

HILL, WR. 1996. Effects of light. In Stevenson, RJ., Bothwell, ML. and Lowe, RL., eds. Algal ecology. San Diego: Academic Press. p. 121-144.

HILLEBRAND, H., and SOMMER, U. 1999. The nutrient stoichiometry of benthic microalgal growth: Redfield proportions are optimal. Limnology and Oceanography, vol. 44, p. 440-446. http://dx.doi. org/10.4319/lo.1999.44.2.0440

HUSZAR, VLM., BICUDO, DC., GIANI, A., FERRAGUT, C., MARTINELLI, LA. and HENRY, R. 2005. Subsídios para a compreensão sobre a limitação de nutrientes ao crescimento do fitoplâncton e perifíton em ecossistemas continentais lênticos no Brasil. In Roland, F., César, D. and Marinho, M., eds. Liçóes em Limnologia: fronteiras conceituais. São Carlos: RiMa Editora. p. 243-260.

JONES, JI., YOUNG, JO., EATON, JW. and MOSS, B. 2002. The influence of nutrient loading, dissolved inorganic carbon and higher trophic levels on the interaction between submerged plants and periphyton. Journal of Ecology, vol. 90, p. 12-24. http://dx.doi. org/10.1046/j.0022-0477.2001.00620.x

KAHLERT, M. 1998. C:N:P ratios of freshwater benthic algae. Archiv für Hydrobiologie, vol. 51, p. 105-114.

KAHLERT, M., HASSELROT, AT., HILLEBRAND, H. and PETTERSSON, K. 2002. Spatial and temporal variation in the biomass and nutrient status of epilithic algae in Lake Erken, Sweden. Freshwater Biology, vol. 47, p. 1-24. http://dx.doi. org/10.1046/j.1365-2427.2002.00844.x
KAHLERT, M. and PETTERSSON, K. 2002. The impact of substrate and lake trophy on the biomass and nutrient status of benthic algae. Hydrobiologia, vol. 489, p. 161-169. http://dx.doi. org/10.1023/A:1023280720576

LANE, CM., TAFFS, KH. and CORFIELD, JL. 2003. A comparison of diatom community structure on natural and artificial substrates. Hydrobiologia, vol. 493, p. 65-79. http://dx.doi. org/10.1023/A:1025498732371

MACKERET, FJH., HERON, J. and TALLING, JF. 1978. Water analysis: some revised methods for limnologists. Kendall: Ed. Wilson, Son Ltd. (Scientific Publication, no. 39).

MCCORMICK, PV. and O'DELL, MB. 1996. Quantifying periphyton responses to phosphorus in the Florida Everglades: a synoptic-experimental approach. Journal of the North American Benthological Society, vol. 15, p. 450-468. http://dx.doi. org/10.2307/1467798

MCCUNE, B. and MEFFORD, MJ. 1999. PC-ORD. Multivariate analysis of ecological data.

MOSCHINI-CARLOS, V., HENRY, R. and POMPÊO, MLM. 2000. Seasonal variation of biomass and productivity of the periphytic community on artificial substrates in the Jurumirim Reservoir (São Paulo, Brazil). Hydrobiologia, vol. 434, p. 35-40. http:// dx.doi.org/10.1023/A:1004086623922

POMPÊO, MLM. and MOSCHINI-CARLOS, V. 2003. Macrófitas aquáticas e perifíton: aspectos ecológicos e metodológicos. São Carlos: RiMa Editora.

RODRIGUES, L. and BICUDO, DC. 2001, Similarity among periphyton algal communities in a lentic-lotic gradient of the upper Paraná river floodplain, Brazil. Revista Brasileira de Botânica, vol. 24, p. 235-248.

REDFIELD, AC. 1958. The biological control of the chemical factors in the environment. American Scientist, vol. 46, p. 205-221.

SARTORY, DP. and GROBBELAAR, JU. 1984. Extraction of chlorophyll a from freshwater phytoplankton for spectrophotometric analysis. Hydrobiologia, vol. 114, p. 177-187. http://dx.doi. org/10.1007/BF00031869

SOLORZANO, L. 1969. Determination of ammonia in natural waters by the phenolhypochlorite method. Limnology and Oceanography vol. 14, p. 799-801. http://dx.doi.org/10.1007/BF00031869

STEVENSON, RJ. 1996. An introduction to algal ecology in freshwater benthic habits. In Stevenson, RJ., Bothwell, ML. \& Lowe, RL., eds. Algal ecology: freshwater benthic ecosystems. San Diego: Academic Press. p. 3-30.

STELZER, RS. and LAMBERTI, GA. 2001. Effects of $\mathrm{N}: \mathrm{P}$ ratio and total nutrient concentration on stream periphytic community, structure, biomass, and elemental composition. Limnology and Oceanography, 
vol. 46, p. 356-367. http://dx.doi.org/10.4319/ lo.2001.46.2.0356

STRICKLAND, JDH. and PARSONS, TR. 1960. A manual of sea water analysis. Bulletin of the Fisheries Research Board of Canada, vol. 125, p. 1-185.

TOWNSEND, SA. and GELL, PA. 2005. The role of substrate type on benthic diatom assemblages in the Daly and Roper Rivers of the Australian wet/dry tropics. Hydrobiologia, vol. 548, p. 101-115

UMBREIT, WW., BURRIS, RH. and STAUFFER, JF. 1964. Manometric methods applicable to the study of tissue metabolism. Ed. Burgess Publishing Company. p. 208-209.

VADEBONCOEUR, Y. and STEINMAN, AD. 2002. Periphyton function in lake ecosystems. Scientific World Journal, vol. 2, p. 1-20.

VALDERRAMA, GC. 1981. The simultaneous analysis of total nitrogen and total phosphorus in natural waters. Marine Chemistry, vol. 10, p. 109-112. http:// dx.doi.org/10.1016/0304-4203(81)90027-X

VERCELLINO, IS. and BICUDO, DC. 2006, Sucessão da comunidade de algas perifíticas em reservatório oligotrófico tropical (Sáo Paulo, Brasil): comparação entre período seco e chuvoso. Revista Brasileira de Botânica, vol. 29, p. 363-377.

WALKER, I. 2004, Trophic interactions within the in Utricularia habitat the reservoir of the Balbina hydroelectric power plant (Amazonas, Brazil). Acta Limnologica Brasiliensia, vol. 16, p. 183-191.

WETZEL, RG. 1993, Microcommunities and microgradients: linking nutrient regeneration, microbial mutualism, and high sustained aquatic primary production. Netherlands Journal of Aquatic Ecology, vol. 27, p. 3-9. http://dx.doi.org/10.1007/ BF02336924

ZANDER, MJV. and VADEBONCOUER, Y. 2002. Fishes as integrators of benthic and pelagic food in lakes. Ecology, vol. 83, p. 2152-2161. 